\title{
MICROCHILUS CAMPANENSIS (ORCHIDACEAE), A NEW SPECIES FROM PANAMA
}

\author{
MarTA KolanowsKa
}

\begin{abstract}
A new species of Microchilus Presl, M. campanensis Kolan., is described from Panamanian material and illustrated. The new species differs from M. pedrojuanensis Ormerod in its spur shape, prominent epichile apical lobe, prominent floral bracts, and irregular apical margins of the petals and dorsal sepal. Information about its habitat and conservation status is provided.
\end{abstract}

Key words: biodiversity, Microchilus, Neotropics, taxonomy

Marta Kolanowska, Department of Plant Taxonomy and Nature Conservation, University of Gdańsk, Wita Stwosza 59, 80-308 Gdańsk, Poland; e-mail: martakolanowska@wp.pl

\section{INTRODUCTION}

The genus Microchilus C. Presl was established by Presl (1827) with two new species, M. major C. Presl and M. minor C. Presl. Ormerod (2002) recently selected the latter as the lectotype of the genus. Representatives of Microchilus have usually been treated as members of Erythrodes (Ames 1922; Schweinfurth 1946; Carnevali \& Dodson 1993; Garay 1977; Dodson 1994; Dressler 2003). This genus was described two years before $M i$ crochilus by Blume (1825) based on Indonesian Physurus latifolius Blume. The two genera are similar in vegetative and floral characters and are classified within subtribe Goodyerinae (Chase et al. 2003). They produce decumbent rhizomes and petiolate leaves. Their inconspicuous resupinate flowers are arranged in a pedunculate, spicate or racemose, pubescent inflorescence. Their bipartite spurred lip is adnate to the gynostemium.

The recent restoration of Microchilus as a separated genus was based on differences in gynostemium morphology observed between Microchilus and Erythrodes. Plants of the former are characterized by a deeply bifid rostellum and linear-clavate viscidium (Ormerod \& Cribb 2003); in the latter the rostellum remnant is shallowly bifid and the viscidium linear or oblong. In the current concept of the geographical range of Microchilus, the genus is limited to the Neotropics (from Mexico and Caribbean to Argentina), and Erythrodes to the Paleotropics from Myanmar to southern China and New Guinea (Ormerod \& Cribb 2003). Paul Ormerod's comprehensive studies of Microchilus (Ormerod 2002, 2005, 2007, 2008, 2009a, b) yielded descriptions of dozens of new species and numerous transfers. With over 130 species it is now the largest genus within Goodyerinae (Ormerod 2009b).

Representatives of this genus usually grow in thick litter in lowland as well as in premontane and montane forests, but several species have been reported above $2000 \mathrm{~m}$ a.s.l. (Ormerod \& Cribb 2003). The most recent catalogue of Panamanian vascular plants (Correa et al. 2004) lists four Microchilus species (all referred as Erythrodes), but Ormerod's studies raised that number to twelve. The new species of the genus described here is based on Panamanian material.

\section{DESCRIPTION OF THE NEW SPECIES}

Microchilus campanensis Kolan., sp. nov.

Figs 1 \& 2

Species similar to M. pedrojuanensis Ormerod, from which it differs in its spur shape, prominent epichile 
apical lobe, prominent floral bracts, and irregular apical margins of the petals and dorsal sepal.

HolotyPe: PANAMA, Panamá, Distrito de Capira. Cerro Campańa, trocha desde el mirador a la cima, alt. 700-1000 m, $8^{\circ} 41^{\prime} \mathrm{N}, 79^{\circ} 55^{\prime} \mathrm{W}, 12$ Jan. 1995, C. Galdames $1877 \&$ \&. Guerrera (PMA).

Plant $45 \mathrm{~cm}$ tall. Leaves gathered in the lower part of the stem, petiolate; sheath and petiole $c a$ $5 \mathrm{~cm}$ long; blade 8-12 cm long, 4.2-6.0 cm wide, elliptic, acuminate. Inflorescence $c a 27 \mathrm{~cm}$ long, densely many-flowered. Flowers small, yellowishwhite, sepals externally sparsely ciliate. Pedicellate ovary 6-7 mm long, ciliate. Floral bracts white 8-12 mm long, elliptic-lanceolate, acuminate. Dorsal sepal ca $5.5 \mathrm{~mm}$ long, $1.2 \mathrm{~mm}$ wide, oblongligulate, obtuse, slightly concave, apical margins irregular, 1-nerved. Petals $5.5 \mathrm{~mm}$ long, $1.1 \mathrm{~mm}$ wide, adnate to dorsal sepal, ligulate, subacute, somewhat curved at apex, apical margins irregular, 1-nerved. Lateral sepals $6 \mathrm{~mm}$ long, $1.1 \mathrm{~mm}$ wide, linear-oblong, obtuse, 1-nerved. Apical 1/5 of lip constricted; lip hypochile $5.5 \mathrm{~mm}$ long, $1.7 \mathrm{~mm}$ wide, oblong, with ovate callus from base to center, margins slightly undulate; epichile $1 \mathrm{~mm}$ long, $3.5 \mathrm{~mm}$ wide, thin, 3-lobed, middle lobe triangular, obtuse, lateral lobes ligulate-lanceolate, apiculate, obtuse. Spur 3.8-4.1 mm long, clavate, apical 1/3 swollen, apiculate, obtuse. Gynostemium 3.1$3.3 \mathrm{~mm}$ long.

ETYMOLOGY. In reference to the type locality.

DistRIBUTION AND HABITAT. So far the species is known exclusively from the eastern slopes of the Panamanian Central Cordillera. It was found in premontane cloud forest at 700-1000 $\mathrm{m}$ a.s.1. Flowering in January.

Notes. In flower morphology M. campanensis resembles $M$. arietinus (Rchb. f. \& Warm.) Ormerod, widely distributed from Bolivia and Brazil to Colombia, but is easily distinguished from it by leaf shape (oblong-lanceolate in M. arieti$n u s$ ) and by having lip callus. Lip shape similar to that of M. campanensis is observed in Panamanian M. fuscatus but the new species differs from it in numerous other characters, including the shape of the tepals and spur and, most of all, the prominent floral bracts (vs floral bracts subequal in length to the ovary) and distinctly acuminate leaves (vs leaves shortly acute). A 3-lobed lip epichile with elongate lateral lobes is also found in M. maasii Ormerod, a rather variable species. Microchilus campanensis can be distinguished from this orchid by its smaller flowers, spur shape (narrowly obovoid-oblongoid in $M$. maasii), narrower lip hypochile (up to $3 \mathrm{~mm}$ in $M$. massii) and glabrous epichile (vs epichile papillose-pubescent in M. massii). The new species resembles $M$. pedrojuanensis Ormerod known from Paraguay but differs in its spur shape (clavate vs subcylindric), epichile shape (3-lobulate vs semilunate), large
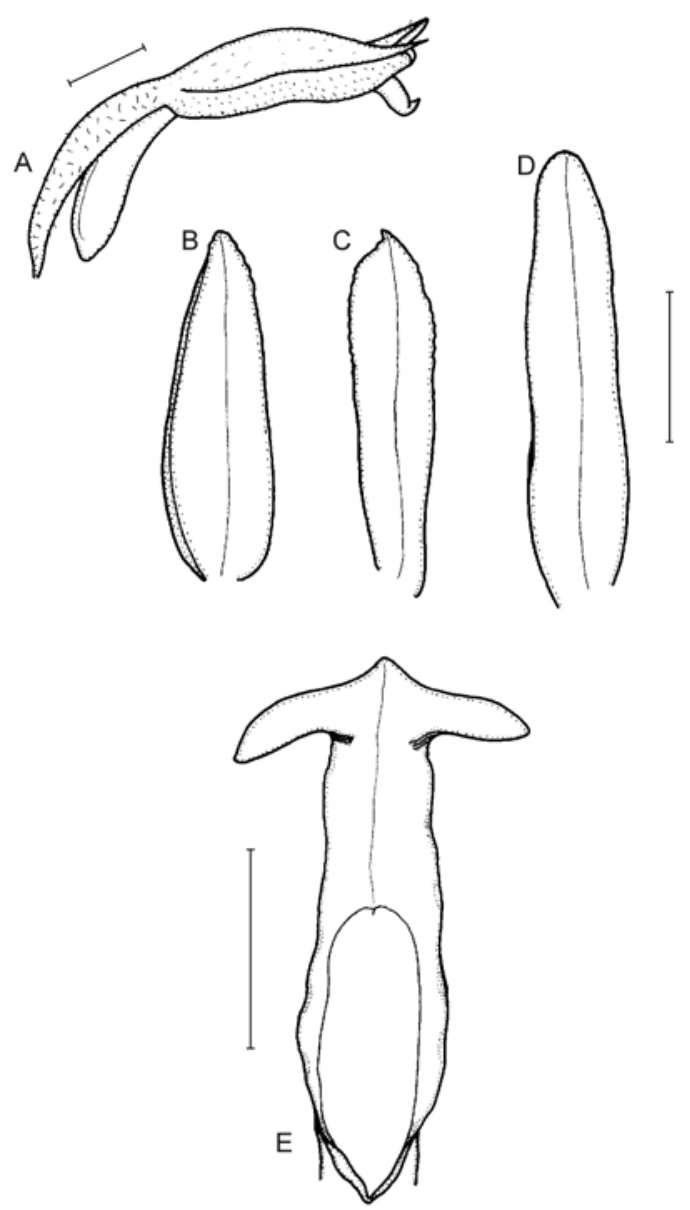

Fig. 1. Microchilus campanensis Kolan., sp. nov. - dissected perianth. A - flower, B - dorsal sepal, C - petal, D - lateral sepal, E - lip. Drawn from the holotype. Scale bars $=2 \mathrm{~mm}$. 


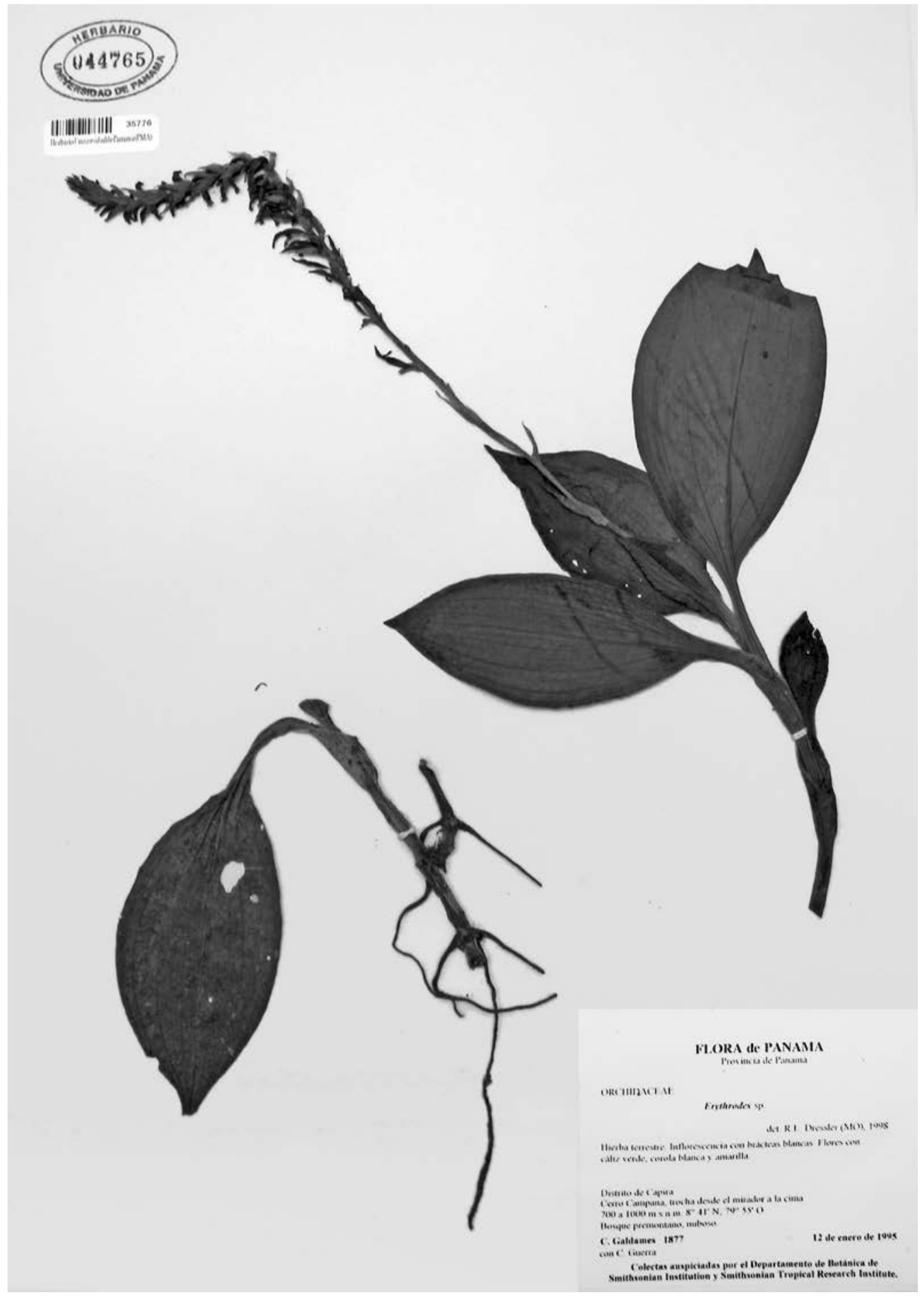

Fig. 2. Microchilus campanensis Kolan., sp. nov. - holotype. 
floral bracts (8-12 $\mathrm{mm}$ vs $5 \mathrm{~mm}$ ) and irregular apical margins of the petals and dorsal sepal (vs margins entire). Another difference is the presence of the ovate callus on the lip of $M$. campanensis.

Conservation STATUS. The species is known only from the type locality. The area is part of Altos de Campana NP, thus its habitat seems not to be under threat, but in the absence of more information it should be classified as DD (data deficient).

ACKNOWLEDGEMENTS. I thank the Curator and staff of the herbarium of the University of Panama (PMA) for their kind hospitality and assistance during my visit, and Professor Dariusz L. Szlachetko and the anonymous reviewers for valuable comments on the manuscript. The research described here was financed by the Faculty of Biology, University of Gdańsk (538-L150B065-13).

\section{REFERENCES}

Ames O. 1922. Notes on Erythrodes with nomenclatorial changes and descriptions of three new species. In: O. AMES, Orchidaceae. Illustrations and studies of the family Orchidaceae. 7: 63-78. The Merrymont Press, Boston.

Blume C. L. 1825. Bijdragen tot de flora van Nederlandsch Indië. 8. Lands Drukkerij, Batavia.

Carnevali G. \& Dodson C. H. 1993. Nomenclatural notes in the Orchidaceae. Lindleyana 8: 101-102.

Chase M. W., Cameron K. M., Barrett R. L. \& FreudenSTEIN J. V. 2003. DNA data and Orchidaceae systematics: a new phylogenetic classification. In: K. W. Dixon, S. P. Kell, R. L. Barrett \& P. J. Cribb (eds), Orchid conservation, pp. 69-89. Natural History Publications, Kota Kinabalu.

Correa M., Galdames C. \& Stapf M. S. 2004. Catálogo de las plantas vasculares de Panamá. Quebecor World, Bogotá.

Dodson C. H. 1994. New Orchid species and combinations from Ecuador 2. Orquideologia 19(2): 123-149.

Dressler R. L. 2003. Orchidaceae. In: B. E. Hammel, M. H. Grayum, C. Herrera \& N. Zamora (eds), Manual de plantas de Costa Rica. 3. Monogr. Syst. Bot. Missouri Bot. Gard. 93: 1-595.

GaraY L. A. 1977. Systematics of the Physurinae in the New World. Bradea 2: 191-208.

OrMerod P. 2002. Taxonomic changes in Goodyerinae (Orchidoideae). Lindleyana 17: 189-238.

OrMERod P. 2005. Studies of neotropical Goodyerinae (Orchidaceae). Harvard Pap. Bot. 9: 391-423.

OrMERod P. 2007. Studies of neotropical Goodyerinae (Orchidaceae) 2. Harvard Pap. Bot. 11: 145-177.

OrMEROD P. 2008. Studies of neotropical Goodyerinae (Orchidaceae) 3. Harvard Pap. Bot. 13: 55-87.

Ormerod P. 2009a. Studies of neotropical Goodyerinae (Orchidaceae) 4. Harvard Pap. Bot. 14: 111-129.

Ormerod P. 2009b. Notulae Goodyerinae (IV). Taiwania 54(1): 45-51.

Ormerod P. \& Cribb P. 2003. Microchilus. In: A. M. PridgeON, P. J. CRibB, M. W. Chase \& F. N. Rasmussen (eds), Genera Orchidacearum. 3: 121-124. Oxford University Press, Oxford.

Presl C. 1827. Orchidaceae. In: T. Haenke (ed), Reliquiae Haenkeanae seu descriptiones et icones plantarum quas in America Meridionali et Boreali, in Insulis Phillipinis et Marianis Collegit (Orchidaceae). 2: 91-104. Calve, Prague.

SchweInfurth C. 1946. Orchidaceae Andinae II. Revista Acad. Colomb. Ci. Exact. 6: 573-577. 